International Journal of Social Sciences and Humanities
Available online at www.sciencescholar.us
Vol. 5 No. 2, August 2021, pages: $68-78$
e-ISSN: 2550-7001, p-ISSN: 2550-701X
https://doi.org/10.29332/ijssh.v5n2.1139

\title{
Relevance of Mastery of Information Systems Skills and Success of Business Management in the Digital Age: A Systematic Review
}

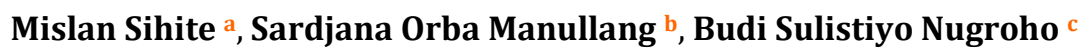

Manuscript submitted: 9 February 2021, Manuscript revised: 18 March 2021, Accepted for publication: 27 April 2021

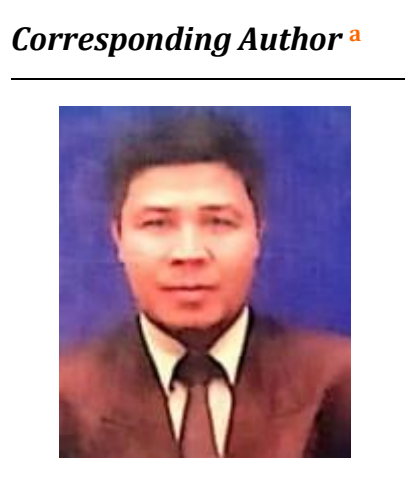

Keywords

business management;

digital age;

systematic review;

technology mastery;

Abstract

The search for the relevance of mastery of skills and mastery of information systems on the success and strength of business management in the digital era is the main objective of our systematic review. We make evidence of the study findings from dozens of international publications that have discussed various themes of ways and approaches to advance or manage the business with the assistance of technology which has become the hallmark of a tool in all business sectors. We conducted an electronic search on all supporting data from Google Scholar from the 2010 to 2021 issue. After obtaining the data, we then analyzed it by involving the coding system, extract data, evaluating, in-depth interpretation, and concluding response to this question with valid findings and high reliability. By considering the existing evidence, we can report the results; there is a significant correlation between technology skills and successful business management. In short, the ability to use the Internet plays a vital role in a business because managers can search and meet a customer for any purpose through search engines. Similarly, the consumers will instantly be able to get what they need using the same tools of technology-savvy.
\end{abstract}

International Journal of Social Sciences and Humanities (C) 2021. This is an open access article under the CC BY-NC-ND license (https://creativecommons.org/licenses/by-nc-nd/4.0/).

\section{Contents}

Abstract

1 Introduction.

2 Materials and Methods.

3 Results and Discussions

4 Conclusion

Acknowledgments..

\footnotetext{
${ }^{a}$ Universitas Methodist Indonesia

${ }^{\mathrm{b}}$ Universitas Krisnadwipayana, Indonesia

${ }^{c}$ Politeknik Energi dan Mineral Akamigas (PEM Akamigas), Indonesia
} 


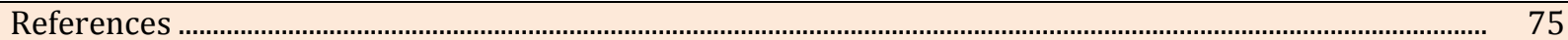

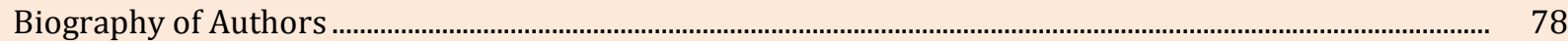

\section{Introduction}

The world has entered the time of the 4.0 mechanical insurgency, where innovative advancements are progressively complex (Mendiratta et al., 2021; Putra \& Aslan, 2020; Putra et al., 2020; Sudarmo et al., 2021). Changes in the modern world have advanced in a few disturbing angles with the rise of supercomputers, intelligent robots, driverless vehicles, distributed computing, substantial information frameworks, hereditary designing, and the improvement of neurotechnology. Moreover, in the 4.0 current upheaval, apparatuses were made that help work with human work like robots to build proficiency and complete work, both in industry, well-being, and in horticulture. This causes numerous kinds of lost and supplanted occupations by the capacity of robots or human-made brainpower; social changes and long haul shifts in business will be felt in the computerized mechanical insurgency. When mechanical improvements sprinted, the abilities controlled by laborers become out of date rapidly (Singh \& Bansal, 2020; Sihite \& Saleh, 2019; Sihite, 2018).

The human labor force does not preclude the chance of confronting new kinds of work that were never considered, so this transformation unavoidably requests that we keep on creating abilities that can be valuable later on. According to Boyles (2016) data and correspondence innovation abilities are expected to confront the modern upheaval 4.0 to have the option to comprehend innovation like worldwide mindfulness, media proficiency and innovation, and a visual education. Furthermore, to confront the current progressive period, we should likewise have delicate abilities, for example, abilities in powerful correspondence that can work in groups and team up, have an individual and social duty, should be intuitive in correspondence, have a public and worldwide direction, have a spirit. Administration and duty have morals and virtues, profitability and responsibility, variation and diversity, activity and self-heading. In this manner, it is trusted that current laborers should set themselves up to have data and correspondence innovation abilities to confront the period of the mechanical transformation 4.0 so they can adjust to the evolving times (Agolla, 2018).

The Industrial Revolution 4.0, which is being felt and accepted to have the option to improve the personal satisfaction of the populace and the request for life throughout the planet, is anticipated to achieve social change and a change in business perspectives (Bagnoli et al., 2019). Profitability and productivity are warm long-haul gestures that will be felt in this advanced modern upset; like this, organizations should have the option to exploit this quickly, creating innovation to have the option to accomplish a more elevated level of adequacy of creation and utilization just as an improvement into new business sectors. With the presence of innovation like engineered knowledge (impersonation), the web, and programmed machines, it may be executed in regular day-to-day existence that can change the idea of an organization, the outlook of people made in light of this 4.0 modern insurgency. In the current unrest 4.0, beginning from the transportation business to retail and banking, they will contend with joining mechanical advancement into their operational cycles because essentially, organizations will be less severe if their innovation is less refined and quick (Levinson, 2016).

All things being equal, contemplates showing that computerized reasoning innovation will preclude and even dispense for certain positions as encourage interest for new abilities and occupations (Susskind \& Susskind, 2015). A few specialists communicated that laborers who comprehend innovation would be remunerated with huge wages, and laborers who do not comprehend innovation will be abandoned. The mechanical upset 4.0, which has the qualities of a blend of innovation, does not depict the reasonable limits between natural, advanced, and physical, which is set apart by the presence of a few new mechanical leap forwards in different fields, including human-made brainpower, mechanical technology, instruction, financial matters, and others. Monstrous information use and preparation is the principle or significant factor that underlies these forward leaps. Presently information has developed into a weapon in winning the opposition in different fields, not just a correlative factor (Alshare et al., 2011).

As one of the enormous nations on the planet, Indonesia can be an expansive and colossal information maker and client. It is not hard for the Indonesian public to discover proof of enormous or unadulterated utilization of information and innovation since they can be discovered effectively in regular day-to-day existence (Doctoroff, 2014). As delivered by the World Economic Forum (Future of occupations), it was

Sihite, M., Manullang, S. O., \& Nugroho, B. S. (2021). Relevance of mastery of information systems skills and success of business management in the digital age: a systematic review. International Journal of Social Sciences and

Humanities, 5(2), 68-78. https://doi.org/10.29332/ijssh.v5n2.1139 
discovered that there were a few advancements that were fervently examined in 2018-2022 alongside this 4.0 current unrest. Here is a portion of the innovations that will rule: Fast mobile web that is a quick web association on cell phones, is the primary establishment in modern transformation 4.0. Furthermore, we are utilizing the $4 \mathrm{G}$ organization, which has an association speed that is very fit yet is not equally utilized. Aside from that, the improvement of the $5 \mathrm{G}$ organization has started to be declared and will be distributed for cell phones in 2019-2020 (Ramiro \& Hamied, 2011; Cheney et al., 1990).

In 2020 it was anticipated that it would be ideal for Indonesia to apply the 5G organization foundation since it requires some investment for industry players to think about organizing guidelines and instructing the general population as per mechanical time 4.0. Computerized reasoning (Dadios et al., 2018; Brinkkemper, 1996). Examines how to make a PC that can do things usually done by people and is relied upon to be superior to people themselves. This human-made consciousness can be a more modernized PC with the teaching of human-like insight or more. One type of human-made consciousness in the mechanical period 4.0 is the utilization of water-driven robots to gather a motor to make get-together simpler. Large Data Analytic Is a term that portrays the aggregate or the immense measure of information, regardless of whether it is organized or unstructured. The utilization of enormous information in modern insurgency 4.0 can be utilized and broke down to add experiences that lead to more amazing showcasing choices and systems. There are three significant parts in this enormous information, including volume, assortment, and speed. Huge information is additionally a possibility for innovation patterns in industry 4.0 due to such an excess of information that can be dissected to track down the correct answer for the issue (Sahana et al., 2020; Heeks, 2006; Mun \& Hwang, 2003).

This quickly developing innovation permits us to contemplate what this advancement will achieve or bring. Questions and contemplations will keep springing up to everyone (Desjardins \& Bullock, 2019). Is it about whether the numerous advantages come about because of this innovation or the numerous awful impacts of this advancement? To react to this advancement and improvement, we should have the option to have a benchmark or benchmark not simply on one platform. At the point when where it is malicious, there is additionally truth.

Furthermore, when there is a dark side, there must likewise be a bright side as well. So people are needed to have an expansive view. Ideally, with this article, perusers can be relied upon to give an outline and can likewise be utilized as a benchmark so they can contemplate mechanical advances, use them reasonably, and offset innovative advances with the request forever-the evolving times (Speck, 2014; Peppard \& Ward, 2004; Theuri \& Gunn, 1998).

\section{Business Management Success}

Organizations or organizations that are exceptionally effective are no particular case for how superstars run the organization they run (Anderson \& Anderson, 2010). This is remembered for the administrative capacity, which is the main thing for a business entertainer or money manager. Understanding administration by specialists can be said as a cycle of preparation, controlling, and using all assets to accomplish focuses on that have been carried out. The business has significance as a movement that plans to sell merchandise or administrations. Then, the board of the executives is from English which comes from the word control which has the importance of help. When all is said in done, the board exercises are partitioned into a few classifications, including the accompanying (Gibbons, 2015; Manullang, 2020; Manullang et al., 2020).

Talking about business management means it is necessary to understand what management is, including marketing in today's digital economy concept. Wymbs (2011) in his paper, said that digital marketing is now the most up-to-date solution. Now is the time for a new academic major to have arrived. With the digital era like today, marketing management has made many changes that can make companies survive and even surpass the competition in the digital era. Of course, any changes made by adjusting to the digital era will have a progressive impact because several concepts can be applied to understand the meaning of marketing management in the digital era and digital startups (Ansong \& Boateng, 2019). Another essential aspect of business management is production governance. Because the concept of product marketing management, according to Barquet et al. (2013) is a concept in which companies reduce production costs as much as possible to get more profit. To carry out the concept of production management, companies usually reduce production costs and low so they can get a profit (Cooper, 2017). 
The trick is to come up with as many products as possible to sell. A concept like this would be suitable for fast-moving businesses such as home clothes or even raw materials that people often use. Other governance includes product concept management which is marketing management that uses product-oriented concepts like the made product. Companies focus on providing the best products to give to their customers. Of course, customers will be satisfied with a good product and become loyal to the company's products (Kooper et al., 2011). This concept will be suitable if the company targets the middle to upper market, which is more concerned with good product quality regardless of the price. Of course, if a business wants to focus on product quality, the resulting product will have a price that is also expensive (Wells et al., 2011). Sales concept in sales concept, the company believes that attracting customers is an attractive sales system. Usually, companies will do many ways related to the sales process so that consumers want to buy their products (Andzulis et al., 2012).

According to Osterwalder et al. (2014) this method can be done well, although not consistently successful. One example of the concept of selling a product is giving a customer a discount. Usually, this concept is mainly done by e-commerce or online stores that sell digitally. The marketing concept, also known as this marketing management concept, focuses on what the target market needs. Quite different from the sales concept described earlier, where the marketing concept tends to have loyal and long-lasting customers. It is just that they have to arrange so that the target market is the upper-middle class. Because having a product and using the concept of marketing to market the product means that the company only depends on the needs of its consumers (Hassan, 2012). Another governance, for example, is the social concept of the social marketing concept, which is a marketing concept that focuses on the social impacts that occur (Weinreich, 2010). Using this concept, the company believes that customers will be satisfied with products with a positive social impact. The concept of social marketing in question can be in the form of social impacts on the environment or, for example, on workers affected by COVID-19 during the pandemic.

Another area that goes into business management is the governance of promotion using accounts and creations. Before delving deeper into business management, several tips can sustain this administrative cycle (James, 2015). The goal is for business people to have an image that can help them deal appropriately with the organization or business. A thorough plan and analysis of a task or business, whether large or small, must have an arrangement or plan. Even though businesses are in the beginner stage, the company must have a careful arrangement. Such a guide will help a business or a businessperson's work trip remain centered (Glasgow et al., 2012). Making detailed notes or reports recorded or reports is essential; try to record every movement in the business they face. Make it complete and coordinated, starting with the training done or notes about costs and salaries. Especially for private companies that are developing is essential. Record any monetary movements or whatever needs to be done precisely and effectively. Financial reports or action reports will provide convenience in future examinations (Kim et al., 2010).

Straightforwardly the advantages of organizational tracking/training to increase business success include several rules that can be used as a reference for business executives (Loshin, 2012). The aim is that business people, as operational and financial managers, can see and have the option to supervise depending on the benchmark principles of employee training. Through creation, creation management is an effort to build the comfort of a thing. The manufacturing cycle must be carried out with legal arrangements and executions so that the utilization value can be fulfilled. Herein lies the work of a creation supervisor who controls the exercises that must be completed at a cost and productive time (Sethi et al., 2011). Several stages are used so that the interaction of organizational creations can run efficiently. The investigation and planning stage is to achieve the goal. Determined by the organization, careful arrangements are resolved, starting from the type of equipment used, objective market investigations of the quality required (Delmas \& Montes-Sancho, 2010).

The oversight stage in implementing creative interactions must be directed to fit the business objectives set at the previous business planning stage (Frankenberger et al., 2013). The current size of creation continues to be creative following existing mechanical progress. Several organizations have started to implement it. Various types of creative tools with trend-determining innovations Examples of creative actions that have implemented innovation with technology in their implementation Wheat farmer entrepreneurs, for example, currently have editing machines that can be controlled automatically, this makes it very easy for the workers themselves (Collins \& Mayer, 2010). Many have run programmed equipment such as salty cutting machines, bundling, or pressing for SME organizations. Today's widespread communication utilizes online media to distribute data; this is not the same as in the past when media used paper. The car industry is

Sihite, M., Manullang, S. O., \& Nugroho, B. S. (2021). Relevance of mastery of information systems skills and success of business management in the digital age: a systematic review. International Journal of Social Sciences and Humanities, 5(2), 68-78. https://doi.org/10.29332/ijssh.v5n2.1139 
currently using. The number of automated hands increases in delivering automobile gear (Williams et al., 2012).

Furthermore, the advances above comprehensively have the same goal, namely specifics, so that the administrative cycle can run efficiently, monetary and the like. It has to be centralized so that we can compete with the world's world. Promote Management. Businesses can trace this understanding of promoting executives out there, as many experts have already judged what board advertising is. Business people cannot quote the expressions they speak. Entrepreneurs should understand what the explanation is, why there should be blank spaces in the sidebar. After all, business people can see gaps in business science and tricks of advancement that imply that this blog is being assessed. So if it quotes the master's words to provide a reference, it is likely to be seen as a forgery.

Financial management is also an essential activity in advancing a business. Financial administration is a significant part of each of the points. If a chief financial officer can handle cost development or pay as planned, the organization can do well. Monetary administration actions are recorded utilizing bookkeeping and cover a broader scope of activities within an organization. Business people can familiarize themselves with these monetary administration standards by understanding the material obtained in school, carrying out more indepth investigations so that the business cycle can run properly.

Another business governance is then dispersion management. Dispersion boards can be closed as a push to facilitate the circulation of merchandise or administration from maker to buyer. Altogether, the businessperson can find data about the physical distribution and distribution channels and their parts for complete information. When running a business, the businessman must have some information that must be dominated. Starting from advertising, for example, creating an attractive brand, advancement. This is very powerful from the administrative training that the manager has planned. On that basis, we think that ideally, this study can provide in-depth and additional information and understanding to academics, practitioners, and business policymakers who are looking for data about what business executives are (Benoit et al., 2019).

\section{Materials and Methods}

The search for a deep understanding of the importance ability and dominance of data or information skills to the future achievement and success of business people is the principal objective of our study. We are looking for evidence of study findings from many international distribution publications that have spoken on various subjects on how to deal with advancing or dealing with business with the help of technological innovations that have become a mark of the device in all areas of business today's digital age. We directed an electronic search for all supporting information from Google Scholar from the 2010 to 2021 editions. After obtaining the data, we then broke it down by inserting a coding framework, assessing it, understanding it in-depth, and concluding this investigation with valid findings and high quality. Our study relies on secondary data from the review description framework (Basias \& Pollalis, 2018).

\section{Results and Discussions}

Our first findings on the study objective to find the relevance of mastery of information systems skills and business management success in the digital age through a systematic review were essential. Effective advanced change for homeroom, area, and state is driven not by innovation but by how innovation powers education and learning. This contextual analysis reports on the computerized instructional techniques that educators use to enhance and transform student learning. We study educators' commonalities, uses, and entertainment with innovation as well. McKnight et al. (2016). Teaching in the computerized era: How instructors use innovation to enhance student learning.

The following finding is that small and medium enterprises (SMEs) play an essential role in the European economy. Basic tests are a way of ideally adapting business systems to computerized innovation. There is a dearth of checks examining how electronic initiatives in SMEs foster fruitful arrangements between business procedures and computerized innovations that foster lifespan and development, say the creators. They built hypothetical models and experimental models to help SME pioneers curb advanced innovations on the side of 
their business techniques that empower sustainable development, they said. The next symptomatic model empowers SME leaders to put exciting electronic initiatives into practice. Li et al. (2016) e-Leadership through necessary settings: An observational investigation of small and medium enterprises in the computerized era.

Then Starkey (2011) also assesses learning in the 21st century: aging learning networks. This article describes an assessment tool created using emerging thinking about information creation and learning in concerned societies. The computerized age learning framework was effectively tested and applied to investigate six capable early educators with care during their first year of teaching. The examination found that educators, even those with discretionary abilities, would be limited in their capacity to demonstrate a future age to become dynamic members of a cautiously increasing society regardless of how to apply learning speculation applicable to the computerized age.

Furthermore, Labrecque et al. (2013) examined the power of buyers through evolution in later times. This study investigates the convergence of shopper behavior and high-end media that characterizes buyer power and reinforcement in Internet and web-based media settings. This presents a hypothetical system of four specific buyer resources. Structured sorting out previous marketing posts about strengthening Internet-based buyers was essential that it features holes in the exploration flow and plans diagrams for future inspection areas.

Likewise, Patrick \& Sturgis (2013) are essential for success through building world-class mastery of skills a guide for state policymakers for competency education. A total of 36 states are advancing towards competency schools. The state has been questioned about the time-sensitive frame in operation around Carnegie's unit. Time-sensitive certificates, credit adaptability, or sitting time waivers are other options. This paper explains why conventional time-sensitive frameworks stress our children and our country. It is vital to possess state initiatives to overhaul systems that focus on students, not time-sensitive systems. This paper contains a proposal to create a culture of competence in-state training organizations. It also describes the basis for an emerging strategy that is necessary for a complete set-up.

Furthermore, Attaran et al. (2019) study the requirements for an advanced work environment in expanding the workforce's efficiency in the data age. Representatives are increasingly disappointed with the ability of the work environment. The previous few years had seen an explosion in exploiting the sharp advancement of the work environment. The premium in abusing computerized work environments and innovative workplaces is growing, but acceptance rates are moderate. Done right, the business benefits of an advanced work environment can be enormous. This article investigates the changing components of the work environment and identifies some of the possible benefits of an intelligent work environment.

Similarly, the findings of Petter et al. (2013) through the attainment of a data framework were essential. On a mission for autonomous factors in 1992, DeLone and McLean recommended that reliable variables for data framework (IS) research be successful. We look at the paper on autonomous factors that influence IS achievement. A total of 43 factors were assigned to influence the various elements of IS achievement, and we sorted these attainment factors into five classifications. We present holes in our insight into the factors of progress and propose guidance for future exploration. The authors identified 15 attainment factors that are believed to influence IS achievement and highlighted the importance of combining findings from more than 140 tests.

Likewise, the findings of Alshare et al. (2011) whose business relational skills are in the framework of educational program data through the perspectives of IS instructors and students, were essential. The authors analyze the instructor's data frame and students' impressions of relational abilities in the technology education plan. The results showed that the instructors and students agreed that the information system education program had a proper emphasis on many relational abilities. Nonetheless, the two meetings essentially contrasted in their level of arrangement or conflict with a degree of accentuation. Advice for instructors and scientists is taken into account.

Chang \& Torkzadeh (2013) examined the visible capabilities and capacities required in executives' project data framework. This article writes about the consequences of examining the information systems (IS) project, the various capabilities of the board depending on the two rounds of information assortment from the IS project director and expert. The first stage includes meetings with 47 business heads who are clear evidence of the 12 crucial work of the board of directors. In the second phase, a review was created based on the phase 1 investigation results to gather information from 41 IS project supervisors and experts. The results

Sihite, M., Manullang, S. O., \& Nugroho, B. S. (2021). Relevance of mastery of information systems skills and success of business management in the digital age: a systematic review. International Journal of Social Sciences and Humanities, 5(2), 68-78. https://doi.org/10.29332/ijssh.v5n2.1139 
distinguished the rankings of the 12 abilities as the 12 abilities were also strung into the four classes of Communication and Council Relations, Executive Resources, Change Authority, and Administration.

Finally, we ended our search with Caputo (2010) with gender orientation contrasts in evaluating fundamental business data frameworks and innovation abilities were essential. This exploration study endeavors to discover which Business Information Skills are applicable to understudy concerns. Beginning data was gotten from overviews of a discrete choice of the local corporate area in southwestern Pennsylvania. All reviewed understudies were occupied with at least one of the different Computer Systems programs. The period of the examination, on a continuous premise, envelops the time frame from the academic year 2006 to the scholastic year 2008. Doctoral Information Science programs were excluded from the overview. The second period of the study will look at the connection of the underlying discoveries concerning the sexual orientation of the understudy, both alumni, and undergrad.

\section{Discussion}

In this section, we present a discussion of the study results with the theme of the relevance of mastering information system skills and the success of business management in the digital era through a systematic review.

Some publications that we have reviewed confirm that the understanding and mastery of informatics skills are closely related to managing a business in the era of digital technology. The majority of experts say running a business in the global era is no secret if they do not involve technology in business operations, from planning to marketing management, all of which must involve technology and support for technology-savvy and skilled human resources. The same findings were reviewed by Martín-Rojas et al. (2013) on the effect of technological support, high skills and competencies, and high learning on corporate entrepreneurship among industrialized communities in Europe.

The findings from our study confirm that to support their business processes, companies use technology so that the process is expected to be more efficient, effective, and productive. However, to get maximum results, the application of technology is indispensable as a tool to develop, advance, and sustainably for all parties concerned. In other words, there are several essential benefits of information technology in the business field. Reducing production and operational costs, advances in technology and information can help companies reduce production costs to get big profits by spending less. A similar study was also carried out by Trainor et al. (2011) through a study of the integrity of information technology and marketing towards a trial implementation and achievement of results with e-marketing capability.

\section{Conclusion}

Finally, we conclude at the end of our study report because our explanation has answered the question of this study, namely that there is a close relationship between understanding and proficiency in technology on the success of business governance. We can prove this by examining dozens of publications from international journal databases where they say that whatever effort is made, it is time to involve digital technology to be effective, efficient, and productive, and sustainable.

\section{Acknowledgments}

We, the authors, at this moment, thank all colleagues for their input and feedback from the start of the research work to the completion period. Likewise, our appreciation for the funding sponsorship of this work from the university and the Ministry of Research and Technology. Without their help and support, we could not do much until we completed this project according to our plan on a project entitled "Relevance of Mastery of Information Systems Skills and Success of Business Management in the Digital Age: A Systematic Review". 


\section{References}

Agolla, J. E. (2018). Human capital in the smart manufacturing and industry 4.0 revolution. Digital Transformation in Smart Manufacturing, 41-58.

Alshare, K. A., Lane, P. L., \& Miller, D. (2011). Business communication skills in information systems (IS) curricula: Perspectives of IS educators and students. Journal of Education for Business, 86(3), 186-194.

Anderson, D., \& Anderson, L. A. (2010). Beyond change management: How to achieve breakthrough results through conscious change leadership (Vol. 36). John Wiley \& Sons.

Andzulis, J. "Mick", Panagopoulos, N. G., \& Rapp, A. (2012). A review of social media and implications for the sales process. Journal of Personal Selling \& Sales Management, 32(3), 305-316.

Ansong, E., \& Boateng, R. (2019). Surviving in the digital era-business models of digital enterprises in a developing economy. Digital Policy, Regulation and Governance.

Attaran, M., Attaran, S., \& Kirkland, D. (2019). The need for digital workplace: Increasing workforce productivity in the information age. International Journal of Enterprise Information Systems (IJEIS), 15(1), $1-23$.

Bagnoli, C., Dal Mas, F., \& Massaro, M. (2019). The 4th industrial revolution: Business models and evidence from the field. International Journal of E-Services and Mobile Applications (IJESMA), 11(3), 34-47.

Barquet, A. P. B., de Oliveira, M. G., Amigo, C. R., Cunha, V. P., \& Rozenfeld, H. (2013). Employing the business model concept to support the adoption of product-service systems (PSS). Industrial Marketing Management, 42(5), 693-704.

Basias, N., \& Pollalis, Y. (2018). Quantitative and qualitative research in business \& technology: Justifying a suitable research methodology. Review of Integrative Business and Economics Research, 7, 91-105.

Benoit, S., Klose, S., Wirtz, J., Andreassen, T. W., \& Keiningham, T. L. (2019). Bridging the data divide between practitioners and academics. Journal of Service Management.

Brinkkemper, S. (1996). Method engineering: engineering of information systems development methods and tools. Information and software technology,38(4), 275-280. https://doi.org/10.1016/09505849(95)01059-9

Cheney, P. H., Hale, D. P., \& Kasper, G. M. (1990). Knowledge, skills and abilities of information systems professionals: past, present, and future. Information \& Management, 19(4), 237-247. https://doi.org/10.1016/0378-7206(90)90033-E

Boyles, J. L. (2016). The isolation of innovation: Restructuring the digital newsroom through intrapreneurship. Digital Journalism, 4(2), 229-246.

Caputo, D. (2010). Gender differences in assessing essential business information systems technology skills. International Journal of Management \& Information Systems (IJMIS), 14(2).

Chang, J. C.-J., \& Torkzadeh, G. (2013). Perceived required skills and abilities in information systems project management. International Journal of Information Technology Project Management (IJITPM), 4(1), 1-12.

Collins, J. L., \& Mayer, V. (2010). Both hands tied: Welfare reform and the race to the bottom in the low-wage labor market. University of Chicago Press.

Cooper, R. (2017). Target costing and value engineering. Routledge.

Dadios, E. P., Culaba, A. B., Albert, J. R. G., Paqueo, V. B., Orbeta, A. C., Serafica, R. B., Bandala, A. A., \& Bairan, J. C. A. C. (2018). Preparing the Philippines for the fourth industrial revolution: A scoping study. PIDS Discussion Paper Series.

Delmas, M. A., \& Montes-Sancho, M. J. (2010). Voluntary agreements to improve environmental quality: Symbolic and substantive cooperation. Strategic Management Journal, 31(6), 575-601.

Desjardins, F., \& Bullock, S. (2019). Professional development learning environments (PDLEs) embedded in a collaborative online learning environment (COLE): Moving towards a new conception of online professional learning. Education and Information Technologies, 24(2), 1863-1900.

Doctoroff, T. (2014). Twitter is not a strategy: Rediscovering the art of brand marketing. St. Martin's Press.

Frankenberger, K., Weiblen, T., Csik, M., \& Gassmann, 0. (2013). The 4I-framework of business model innovation: A structured view on process phases and challenges. International Journal of Product Development, 18(3-4), 249-273.

Gibbons, P. (2015). The science of successful organizational change: How leaders set strategy, change behavior, and create an agile culture. FT Press.

Sihite, M., Manullang, S. O., \& Nugroho, B. S. (2021). Relevance of mastery of information systems skills and success of business management in the digital age: a systematic review. International Journal of Social Sciences and Humanities, 5(2), 68-78. https://doi.org/10.29332/ijssh.v5n2.1139 
Glasgow, R. E., Kaplan, R. M., Ockene, J. K., Fisher, E. B., \& Emmons, K. M. (2012). Patient-reported measures of psychosocial issues and health behavior should be added to electronic health records. Health Affairs, 31(3), 497-504.

Hassan, A. (2012). The value proposition concept in marketing: How customers perceive the value delivered by firms-A study of customer perspectives on supermarkets in Southampton in the United Kingdom. International Journal of Marketing Studies, 4(3), 68.

Heeks, R. (2006). Health information systems: Failure, success and improvisation. International journal of medical informatics, 75(2), 125-137. https://doi.org/10.1016/j.ijmedinf.2005.07.024

James, A. (2015). The resource curse: A statistical mirage? Journal of Development Economics, 114, 55-63.

Kim, M., Hoegen, M., Dugundji, J., \& Wardle, B. L. (2010). Modeling and experimental verification of proof mass effects on vibration energy harvester performance. Smart Materials and Structures, 19(4), 045023.

Kooper, M. N., Maes, R., \& Lindgreen, E. R. (2011). On the governance of information: Introducing a new concept of governance to support the management of information. International Journal of Information Management, 31(3), 195-200.

Labrecque, L. I., vor dem Esche, J., Mathwick, C., Novak, T. P., \& Hofacker, C. F. (2013). Consumer power: Evolution in the digital age. Journal of Interactive Marketing, 27(4), 257-269.

Levinson, M. (2016). The Box: How the Shipping Container Made the World Smaller and the World Economy Bigger-with a new chapter by the author. Princeton University Press.

Li, W., Liu, K., Belitski, M., Ghobadian, A., \& O’Regan, N. (2016). e-Leadership through strategic alignment: An empirical study of small-and medium-sized enterprises in the digital age. Journal of Information Technology, 31(2), 185-206.

Loshin, D. (2012). Business intelligence: The savvy manager's guide. Newnes.

Manullang, S. O. (2020). Identification of Newspaper Concerns About the Adaptation Plan for Business Strategies Entering New Normal Era in Indonesia. International Journal of Business, Economics and Management, 3(1), 203-211. https://doi.org/10.31295/ijbem.v3n1.193

Manullang, S. O., Chauhan, R., \& Suthar, B. (2020). A Legal and Economic Study of Selected Private Sector Bank: Performance Evaluation Pre and Post-merger. Organization, 7(11).

Martín-Rojas, R., García-Morales, V. J., \& Bolívar-Ramos, M. T. (2013). Influence of technological support, skills and competencies, and learning on corporate entrepreneurship in European technology firms. Technovation, 33(12), 417-430.

Mun, Y. Y., \& Hwang, Y. (2003). Predicting the use of web-based information systems: self-efficacy, enjoyment, learning goal orientation, and the technology acceptance model. International journal of human-computer studies, 59(4), 431-449. https://doi.org/10.1016/S1071-5819(03)00114-9

McKnight, K., O’Malley, K., Ruzic, R., Horsley, M. K., Franey, J. J., \& Bassett, K. (2016). Teaching in a digital age: How educators use technology to improve student learning. Journal of Research on Technology in Education, 48(3), 194-211.

Mendiratta, S., Mathur, S., Tanwar, D., \& Sharma, S. (2021). Evaluating and Exploring Industry 4.0 Framework. Proceedings of the Second International Conference on Information Management and Machine Intelligence, 41-49.

Osterwalder, A., Pigneur, Y., Bernarda, G., \& Smith, A. (2014). Value proposition design: How to create products and services customers want. John Wiley \& Sons.

Patrick, S., \& Sturgis, C. (2013). Necessary for Success: Building Mastery of World-Class Skills-A State Policymakers Guide to Competency Education. CompetencyWorks Issue Brief. International Association for K-12 Online Learning.

Petter, S., DeLone, W., \& McLean, E. R. (2013). Information systems success: The quest for the independent variables. Journal of Management Information Systems, 29(4), 7-62.

Peppard, J., \& Ward, J. (2004). Beyond strategic information systems: towards an IS capability. The Journal of Strategic Information Systems, 13(2), 167-194. https://doi.org/10.1016/j.jsis.2004.02.002

Putra, P. \& Aslan. (2020). PENGEMBANGAN BAHAN AJAR BERBASIS IMTAQ DAN IPTEK DI ERA REVOLUSI INDUSTRI 4.0 PADA MATA PELAJARAN SAINS MADRASAH IBTIDAIYAH. Ta'Limuna: Jurnal Pendidikan Islam, 9(1), 1-15. https://doi.org/10.32478/talimuna.v9i1.345 
Putra, P., Mizani, H., Basir, A., Muflihin, A., \& Aslan, A. (2020). The Relevancy on Education Release Revolution 4.0 in Islamic Basic Education Perspective in Indonesia (An Analysis Study of Paulo Freire's Thought). Test Engineering \& Management, 83, 10256-10263.

Ramiro, J., \& Hamied, K. (2011). Self-organizing networks: Self-planning, self-optimization and self-healing for GSM, UMTS and LTE. John Wiley \& Sons.

Sahana, S., Singh, D., \& Rakshit, P. (2020). Efficacy of Big Data Application in Smart Cities. Machine Learning and Cognitive Computing for Mobile Communications and Wireless Networks, 225-249.

Sethi, S. P., Veral, E. A., Shapiro, H. J., \& Emelianova, O. (2011). Mattel, Inc.: Global manufacturing principles (GMP)-a life-cycle analysis of a company-based code of conduct in the toy industry. Journal of Business Ethics, 99(4), 483-517.

Sihite, M. (2018). Peran kompetensi dalam mewujudkan sumber daya manusia yang berdaya saing tinggi di era revolusi industri 4.0: Suatu tinjauan konseptual. Jurnal Ilmiah METHONOMI, 4(2), 145-159.

Sihite, M., \& Saleh, A. (2019). Peran Kepemimpinan dalam meningkatkan daya saing perguruan tinggi: Tinjauan konseptual. Jurnal Ilmu Manajemen METHONOMIX, 2(1), 29-44.

Singh, R., \& Bansal, R. (2020). INDUSTRY 4.0 IN INDIA: CHALLENGES \& OPPORTUNITIES. New Paradigm in Business \& Education, 160.

Speck, W. A. (2014). Swift (Routledge Revivals). Routledge.

Starkey, L. (2011). Evaluating learning in the 21st century: A digital age learning matrix. Technology, Pedagogy and Education, 20(1), 19-39.

SUDARMO, Nugraha, M. S., MARDHIAH, R. I.liow, F. E., \& ASLAN. (2021). The Identification of Online Strategy Learning Results While Students Learn from Home During the Disruption of the COVID-19 Pandemic in Indonesia. Journal of Contemporary Issues in Business and Government, 27(2), 1950-1956. https://doi.org/10.47750/cibg.2021.27.02.205

Susskind, R. E., \& Susskind, D. (2015). The future of the professions: How technology will transform the work of human experts. Oxford University Press, USA.

Theuri, P. M., \& Gunn, R. (1998). Accounting information systems course structure and employer systems skills expectations. Journal of Accounting Education,16(1), 101-121. https://doi.org/10.1016/S07485751(98)00005-0

Trainor, K. J., Rapp, A., Beitelspacher, L. S., \& Schillewaert, N. (2011). Integrating information technology and marketing: An examination of the drivers and outcomes of e-Marketing capability. Industrial Marketing Management, 40(1), 162-174.

Weinreich, U. (2010). Languages in contact: Findings and problems. Walter de Gruyter.

Wells, J. D., Valacich, J. S., \& Hess, T. J. (2011). What signal are you sending? How website quality influences perceptions of product quality and purchase intentions. MIS Quarterly, 373-396.

Williams, D. L., Crittenden, V. L., Keo, T., \& McCarty, P. (2012). The use of social media: An exploratory study of usage among digital natives. Journal of Public Affairs, 12(2), 127-136.

Wymbs, C. (2011). Digital marketing: The time for a new "academic major" has arrived. Journal of Marketing Education, 33(1), 93-106.

Sihite, M., Manullang, S. O., \& Nugroho, B. S. (2021). Relevance of mastery of information systems skills and success of business management in the digital age: a systematic review. International Journal of Social Sciences and Humanities, 5(2), 68-78. https://doi.org/10.29332/ijssh.v5n2.1139 


\section{Biography of Authors}

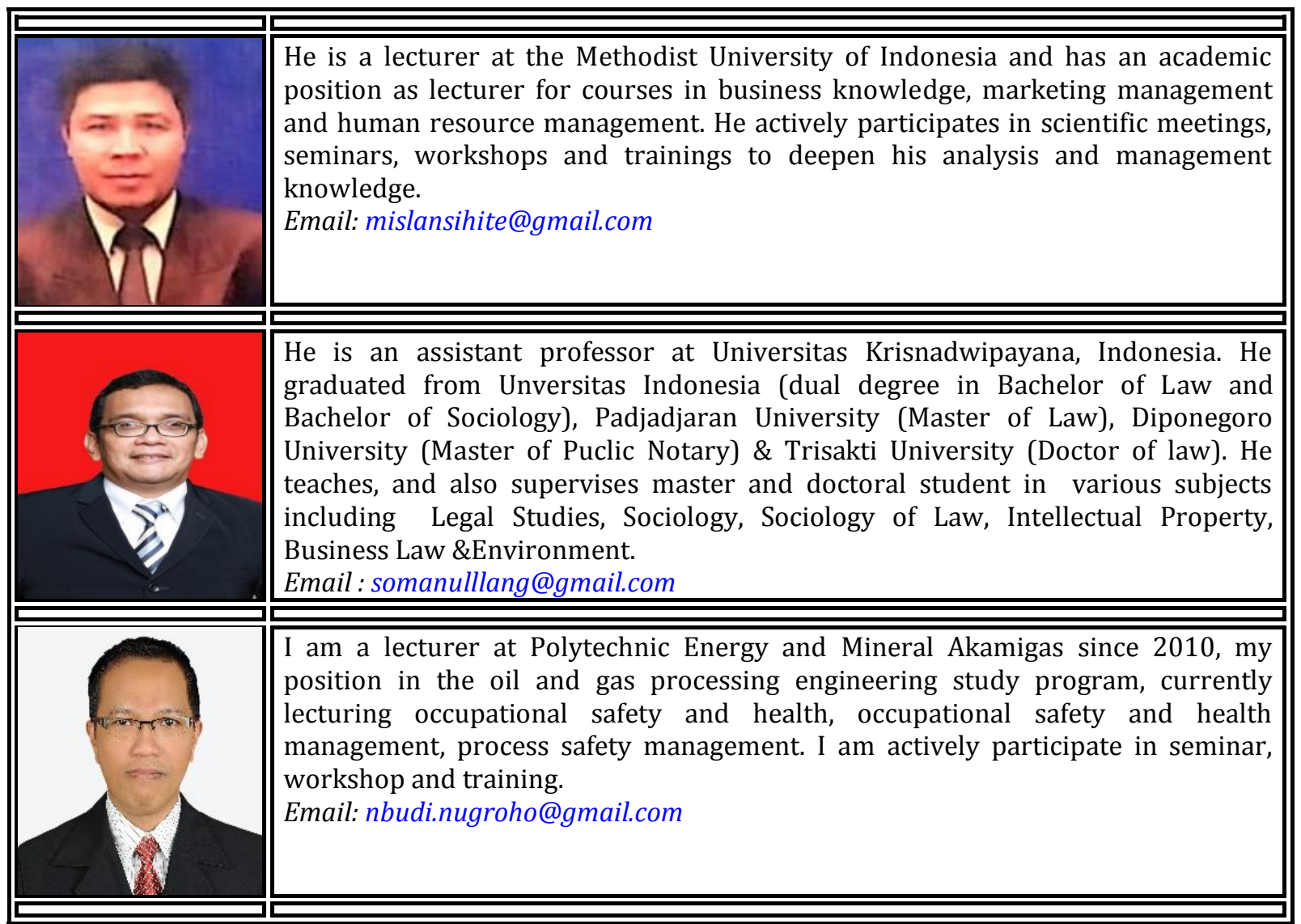

